\title{
Employee Performance Scale: Using (CFA) On Jumhouria Bank in Libya
}

\author{
Esmael M. A. Tabouli ${ }^{1}$, Nasser Habtoor ${ }^{2}$, Mohammad Nashief S. $^{3}$ \\ ${ }^{1,2,3}$ Faculty of leadership and Management, Universiti Sains Islam Malaysia \\ E-mail: e.etbouly@yahoo.com
}

\begin{abstract}
The present study seeks to develop a conceptual framework for measuring employee performance in banking institutions by adopting four appropriate dimensions of measurement: Efficiency of the work, Planning the Work, creativity and innovation and Making Efforts. To achieve this goal, we used a confirmatory factor analysis (CFA) through AMOS software. Based on the results, it was found that this model is a valid and reliable model that can be used for measuring employee performance in banking institutions in Libya.
\end{abstract}

Keywords: Efficiency of the work, Planning the Work, creativity and innovation, Making Efforts

\section{Introduction}

Performance measurement is the "Processes involving managers, individuals and teams based on shared understanding, which define performance and contribution expectations, assess performance against those expectations, provide for regular and constructive feedback and inform agreed plans for performance improvement, learning and personal development" (Armstrong \& Murlis 2004:8). According to Gibson (1990:58), performance is measured in terms of productivity, job satisfaction, turnover and absenteeism." For the purpose of this dissertation, the researcher's definition will be as follows: Performance management or measurement refers to the on-going means by which an organization monitors, documents, corrects or rewards individual and collective employee performance in an organization, using various tools.

Mathis \& Jackson (2009) the employee performance is associated with quantity of output, quality of output, timeliness of output, presence / attendance on the job, efficiency of the work completed [and] effectiveness of work completed. Performance is the accomplishment of a given task measured against pre-set standards of accuracy, completeness, cost and speed (Business Dictionary 2010: online).

employee performance measurement is the "Processes involving managers, individuals and teams based on shared understanding, which define employee performance and contribution expectations, assess performance against those expectations, provide for regular and constructive feedback and inform agreed plans for employee performance improvement, learning and personal development" (Armstrong \& Murlis 2004:8). According to Gibson (1990:58), “...performance is measured in terms of productivity, job satisfaction, turnover and absenteeism." For this study, the researcher's definition will be as follows: Performance management or measurement refers to the on-going means by which Efficiency of Carrying out the Work, Planning the Work, creativity and innovation and Making Efforts, using various tools.

\section{Research Objectives}

Generally, the study aims to test the validity of the employee performance scale as a latent factor by testing the convergent validity known as the average variance extracted (AVE) for each dimension of the main scale, which are the Efficiency of the work, Planning the Work, creativity and innovation and Making Efforts) as well as the items representing them. It also aimed to test the divergent validity known as shared variance (SV) among the investigated dimensions in order to be relying upon them in carrying out tests of correlations and effects or impact with other underlying factors.

\section{Research Methodology}

\subsection{Population and Sample of the Study}

The study population consisted of all employees in the main bank of the republic and its branches in the city of Tripoli, totaling (3100) employees. Initially, 450 samples were preliminary determined to conduct our analysis, while the returned questionnaires valid for the analysis were 381 questionnaires, which all conformed to the requirements of the analysis.

\subsection{Research Instrument}

The researchers designed a questionnaire to test the construct validity of the factor of employee performance based on some previous studies (Nassazi, 2012, (THI, 2012) ; The first dimension, Efficiency of the work, comprises 5 items, and the second dimension, Planning the Work, consists of 5 items, while the third dimension, creativity and innovation, has 6items, last dimension making efforts comprises 7 items. Thus totaling a number of 23items for the questionnaire used for measuring employee performance after testing its external validity (expert judgment). This was achieved by giving the questionnaire to experts in this area. 


\section{International Journal of Science and Research (IJSR) \\ ISSN (Online): 2319-7064}

Index Copernicus Value (2013): 6.14 | Impact Factor (2015): 6.391

\subsection{Confirmatory Factor Analysis (CFA)}

In order to test the validity constructs and the research hypotheses the Structural Equation Modeling (AMOS) model-fitting program is used. The model fit is evaluated by using four indices of the model goodness-of-fit: (1) the comparative fit index (CFI) (2) the chi-square statistics McDonald and Marsh (1990) ; (3) (RMSEA) between (0.08) to (0.10) indicates a mediocre fit Browne and Cudeck (1993) and would not employ a model a RMSEA greater than 0.1 (>0.1) (MacCallu um et al., 1996). (4) the minimum value of the discrepancy between the observed data and the hypothesised model divided by degrees of freedom (CMIN/DF) or normed chi-square. Marsh and Hocevar (1985) ;

\subsection{Construct Validity}

According to Hair, Black, Babin, Anderson and Tatham (2006) the employment of factor loading composite reliability $(\mathrm{CR})$ and average variance extracted (AVE) to determine the convergent validity if it equals to or greater than $0.5(\geq 0.5)$. Also, (AVE) reading values should be greater than $0.5(\geq 0.5)$ (Fornel and Larker, 1981).

\section{Results}

\subsection{The Modified Model}

From Figure (1) that shows the results of the (CFA) for the proposed model for measuring employee performance, it is evident that the model is free of the illogical correlation since it reaches or exceeds the integer (1). This also indicates that there is not any problems in the (CFA) used for testing the validity of this model that comprises four factors: Efficiency of the work, Planning the Work, creativity and innovation and Making Efforts. As seen in Figure (1) and Table (1), the indicators of agreement between the model and the data exceeded the T-value, thus, implying that there is disagreement between employee performance and the data of the sample since the value of the Chi-Square was (822.590) and the degree of freedom was (132), and the level of significance was $(\mathrm{P}=0.000)$. In addition, we can see that the normative ChiSquare (Chi-Square /degrees of freedom) was (3.672) being below than (5), and the value of relative strength index (CFI) was (0.891) less thanthe (0.90). Due to this contradiction between the model and the data, it was necessary to modify the employee performance model in this study.

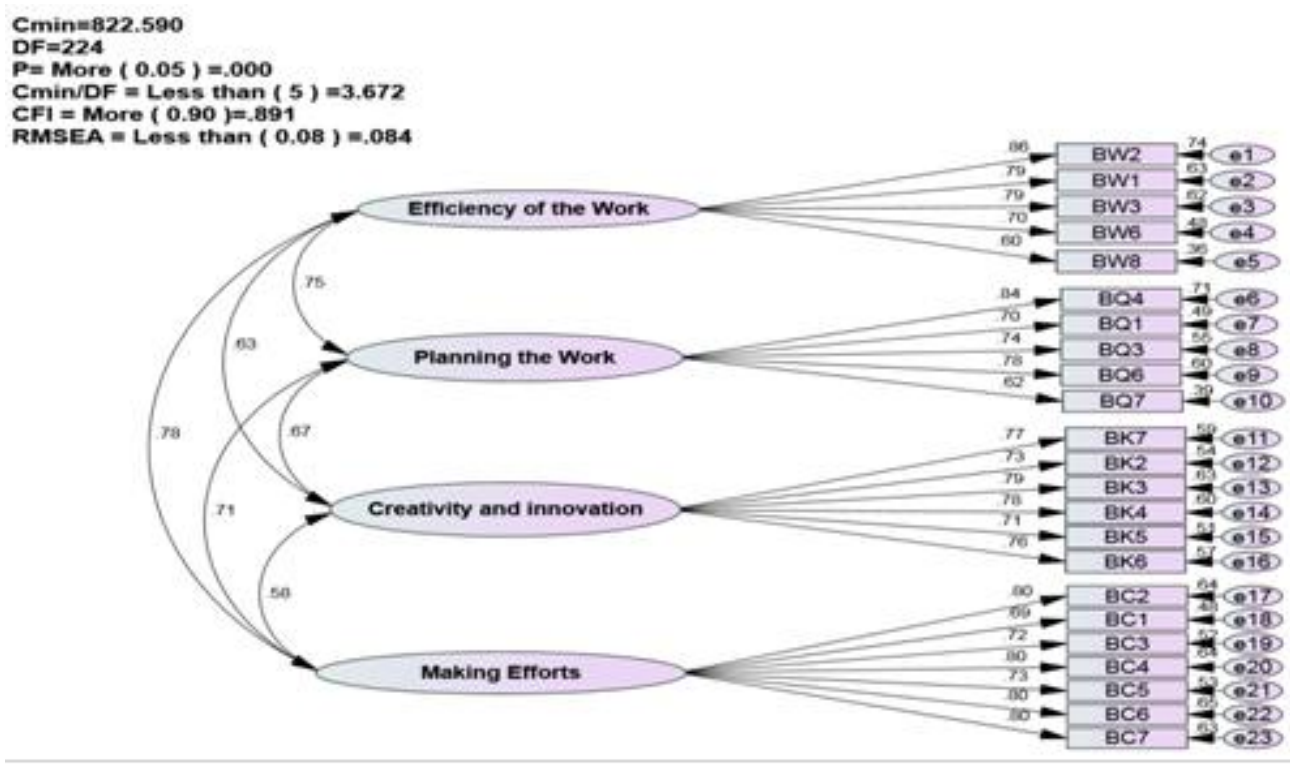

Figure 1: Model employee performance before the amendment

In order to modify this model, we followed was deleting (BW8) of the Efficiency of the Work and also deleting item according (BQ7) of the Planning the. In addition to we followed was deleting (BK5) of the creativity and innovation and $(\mathrm{BC} 1,3,5)$ of the Making Efforts. To what is shown in Figure (2) and to what Amos confirmed by analysis of Amos.
Table 1: Index value of employee performance model before and after modification

\begin{tabular}{|c|c|c|c|}
\hline $\begin{array}{c}\text { Indicators } \\
\text { Consistency }\end{array}$ & $\begin{array}{c}\text { index value } \\
\text { before } \\
\text { modification }\end{array}$ & $\begin{array}{c}\text { index value } \\
\text { after } \\
\text { modification }\end{array}$ & $\begin{array}{c}\text { Function } \\
\text { value on the } \\
\text { quality of } \\
\text { conformity }\end{array}$ \\
\hline $\mathrm{Cmin}$ & 822.590 & 250.550 & --- \\
\hline $\mathrm{df}$ & 224 & 113 & --- \\
\hline $\mathrm{P}$ & 0.000 & 0.000 & Non \\
\hline $\mathrm{Cmin} / \mathrm{Df}$ & 3.672 & 2.217 & Less than (5) \\
\hline $\mathrm{CFI}$ & 0.891 & 0.964 & More (0.90) \\
\hline $\mathrm{Rmsea}$ & 0.084 & 0.057 & $\begin{array}{c}\text { Less than } \\
(0.08)\end{array}$ \\
\hline
\end{tabular}




\section{International Journal of Science and Research (IJSR)}

ISSN (Online): 2319-7064

Index Copernicus Value (2013): 6.14 | Impact Factor (2015): 6.391

\subsection{Confirmatory Factor Analysis of the employee performance model}

The results of the goodness-of-fit of the final revised of the employee performance model showed that normed chisquare (CMIN/DF) was (2.217), the (CFI) was (0.964) and Rmsea was (0.570). Figure (2) shows the adequacy of the final revised of the employee performance model.

\subsection{Construct Validity:}

\subsubsection{Efficiency of the Work}

In the present study, lodging for the parameters factor ranged from 0.66 to 0.89 , with all parameters was above $0.5(\geq 0.5)$. In addition, the AVE reading was 0.62 where the value was greater than $0.5(\geq 0.5)$. Consequently, all results fulfilled the AVE, and the reliability discriminant validity of the model. In general, the first Dimension of the employee performance model was fit and fulfilled the construct as depicted in Table (2).

Table 2: Construct Validity of employee performance model- Efficiency of the Work

\begin{tabular}{|c|c|c|c|c|c|c|c|c|}
\hline Code & Items & Estimate & S. E & $C . R$. & $P$ & Loading & $S M C$ & $A V E$ \\
\hline BW2 & $\begin{array}{l}\text { I feel dedication, seriousness and } \\
\text { ability to take responsibility. }\end{array}$ & 1.000 & - & - & - & 0.89 & 0.80 & 0.62 \\
\hline BW1 & $\begin{array}{l}\text { I enjoy professional skill or } \\
\text { professionalism and technical } \\
\text { knowledge required to carry out the } \\
\text { work efficiently. }\end{array}$ & 0.925 & 0.047 & 19.737 & 0.00 & 0.81 & 0.65 & - \\
\hline BW3 & $\begin{array}{l}\text { I do my work according to specific } \\
\text { policies and procedures. }\end{array}$ & 0.875 & 0.047 & 18.470 & 0.00 & 0.78 & 0.60 & - \\
\hline BW6 & $\begin{array}{l}\text { I feel satisfied with the work I do in } \\
\text { the bank. }\end{array}$ & 0.725 & 0.050 & 14.520 & 0.00 & 0.66 & 0.44 & - \\
\hline
\end{tabular}

\subsubsection{Planning the Work}

In the current study, the lodging for the parameters factor ranged from 0.70 to 0.87 , with all parameters was above $0.5(\geq 0.5)$.
In addition, the AVE reading was 0.60 where the value was greater than $0.5(\geq 0.5)$. Consequently, all results fulfilled the AVE, and the reliability discriminant validity of the factor. In general, the second Dimension of the employee performance model was fit and fulfilled the construct as depicted in Table (3).

Table 3: Construct Validity of employee performance model- Planning the Work

\begin{tabular}{|c|l|c|c|c|c|c|c|}
\hline Code & \multicolumn{1}{|c|}{ Items } & Estimate & S. E & C. $R$. & Poading & SMC & AVE \\
\hline BQ4 & $\begin{array}{l}\text { Planning the work before starting its } \\
\text { implementation contributes to } \\
\text { setting the goals that need to be } \\
\text { achieved. }\end{array}$ & 1.000 & - & - & 0.87 & 0.76 & 0.60 \\
\hline $\mathbf{B Q 1}$ & $\begin{array}{l}\text { I have the ability to plan my work } \\
\text { and its accomplishment according to } \\
\text { the planned schedule. }\end{array}$ & 0.804 & 0.054 & 14.994 & 0.00 & 0.70 & 0.48 \\
\hline $\mathbf{B Q 3}$ & $\begin{array}{l}\text { Planning the work before starting its } \\
\text { implementation gives me a sense of } \\
\text { comfort. }\end{array}$ & 0.891 & 0.053 & 16.831 & 0.00 & 0.76 & 0.57 \\
\hline $\begin{array}{l}\text { Planning the work before starting its } \\
\text { implementation increases my ability } \\
\text { to focus on the completion of the } \\
\text { work assigned automatically. }\end{array}$ & 0.904 & 0.054 & 16.797 & 0.00 & 0.76 & 0.57 & - \\
\hline
\end{tabular}

\subsubsection{Creativity and innovation}

In this study, the lodging for the parameters factor ranged from 0.72 to 0.85 , with all parameters were above 0.5 $(\geq 0.5)$. In addition, the AVE reading was 0.60 where the value was greater than $0.5(\geq 0.5)$. Consequently, all results fulfilled the AVE, and the reliability discriminant validity of the Dimension. In general, the third Dimension of the employee performance model was fit and fulfilled the construct as depicted in Table (4). 


\section{International Journal of Science and Research (IJSR) \\ ISSN (Online): 2319-7064}

Index Copernicus Value (2013): 6.14 | Impact Factor (2015): 6.391

Table 4: Construct Validity of employee performance model- creativity and innovation

\begin{tabular}{|c|l|c|c|c|c|c|c|c|}
\hline Code & \multicolumn{1}{|c|}{ Items } & Estimate & S. $E$ & C. R. & $P$ & Loading & SMC & AVE \\
\hline BK7 & $\begin{array}{l}\text { I am careful or keen to make } \\
\text { changes in the working methods of } \\
\text { each period. }\end{array}$ & 1.000 & - & - & - & 0.77 & 0.59 & $\mathbf{0 . 5 9}$ \\
\hline $\mathbf{B K 2}$ & $\begin{array}{l}\text { I stay away from repeating what } \\
\text { others do in solving work-related } \\
\text { problems. }\end{array}$ & 0.904 & 0.061 & 14.721 & 0.00 & 0.75 & 0.56 & - \\
\hline $\mathbf{B K 3}$ & $\begin{array}{l}\text { I feel bored of repeating the same } \\
\text { procedures in doing the work. }\end{array}$ & 0.917 & 0.056 & 16.413 & 0.00 & 0.82 & 0.68 & - \\
\hline $\mathbf{B K 4}$ & $\begin{array}{l}\text { I have the ability to put forward } \\
\text { ideas and solutions rapidly to face } \\
\text { work-related problems. }\end{array}$ & 0.901 & 0.059 & 15.156 & 0.00 & 0.77 & 0.59 & - \\
\hline $\mathbf{B K 6}$ & $\begin{array}{l}\text { I have the ability to express my } \\
\text { thoughts fluently and freely. }\end{array}$ & 0.868 & 0.059 & 14.648 & 0.00 & 0.74 & 0.55 & \\
\hline
\end{tabular}

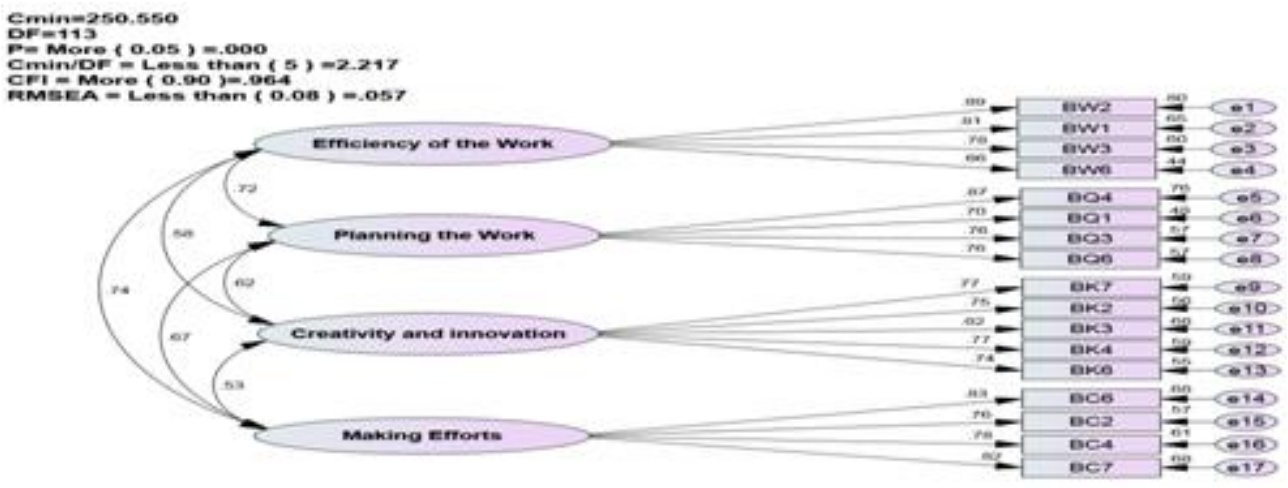

Figure 2: Employee performance model after amendment

\subsubsection{Making Efforts}

In the current study, the lodging for the parameters factor ranged from 0.76 to 0.83 , with all parameters was above $0.5(\geq 0.5)$. In addition, the AVE reading was 0.64 where the value was greater than $0.5(\geq 0.5)$. Consequently, all results fulfilled the AVE, and the reliability discriminant validity of the Dimension. In general, the third Dimension of the employee performance model was fit and fulfilled the construct as depicted in Table (4).

Table 5: Construct Validity of employee performance model- Making Efforts

\begin{tabular}{|c|l|c|c|c|c|c|c|c|}
\hline Code & \multicolumn{1}{|c|}{ Items } & Estimate & S. $E$ & C. $R$. & $P$ & Loading & SMC & AVE \\
\hline BC6 & $\begin{array}{l}\text { Feeling proud of the work } \\
\text { represents a motivation for me } \\
\text { to make extra efforts. }\end{array}$ & 1.000 & - & - & - & 0.83 & 0.68 & $\mathbf{0 . 6 4}$ \\
\hline $\mathbf{B C 2}$ & $\begin{array}{l}\text { I have the desire and willingness } \\
\text { to work outside official working } \\
\text { hours for fast delivery. }\end{array}$ & 0.944 & 0.059 & 16.140 & 0.00 & 0.76 & 0.57 & - \\
\hline BC4 & $\begin{array}{l}\text { The bank is keen on providing } \\
\text { additional benefits to employees } \\
\text { to motivate them to make more } \\
\text { efforts. }\end{array}$ & 0.954 & 0.057 & 16.816 & 0.00 & 0.78 & 0.61 & - \\
\hline BC7 & $\begin{array}{l}\text { The administration provides } \\
\text { those employees who do their } \\
\text { work tasks well with an increase } \\
\text { in the wages or salaries. }\end{array}$ & 0.987 & 0.055 & 18.051 & 0.00 & 0.82 & 0.68 & - \\
\hline
\end{tabular}

\subsection{Fornell -Larcker Criterion}

As seen in Table (6), the SV among the three dimensions is the result of multiplication of the correlation value by itself and from the results in the same table regarding the AVE.
It is evident that the AVE for every dimension of the employee performance scale was higher than the SV among all the dimensions. Such result suggests that employee performance model met Fornell -Larcker Criterion and achieved the required predictive validity among its four investigated dimensions. 


\section{International Journal of Science and Research (IJSR) \\ ISSN (Online): 2319-7064}

Index Copernicus Value (2013): 6.14 | Impact Factor (2015): 6.391

Table 6: Covariance and the contrast between the extracted three-dimensional matrix employee performance scale

\begin{tabular}{|c|c|c|c|c|c|}
\hline No & Latent Variables & Efficiency & Planning the Work & $\begin{array}{c}\text { Creativity and } \\
\text { Innovation }\end{array}$ & Making Efforts \\
\hline 1 & Efficiency & $\underline{\mathbf{0 . 6 2}}$ & - & - & - \\
\hline 2 & Planning the Work & 0.52 & $\underline{\mathbf{0 . 6 0}}$ & - & - \\
\hline 3 & creativity and innovation & 0.34 & 0.38 & $\underline{\mathbf{0 . 5 9}}$ & - \\
\hline 4 & Making Efforts & 0.55 & 0.45 & 0.28 & $\mathbf{0 . 6 4}$ \\
\hline
\end{tabular}

\section{Conclusion}

This paper achieved the main goal of the study which was to test the validity of a proposed model for measuring employee performance scale among in financial institutions through the use of a CFA as a means to structural equation modeling (SEM-AMOS). This was proposed and developed based on the identified measurement dimensions of the main factor (employee performance) in previous studies Sultan, Th., Nazim, A., Qader, B. and Khan, Z. (2010), and Uzma Hafeez. (2015). The results obtained in the present study especially regarding the validity of the measurement indicated the constructed model in its four dimensions is a valid measurement tool that can be used in measuring the staff's commitment within banking institutions. The model achieved the required convergent validity or the AVE, among its three dimensions which even exceeded (0.50). The study also proved that the model achieved the required divergent validity or SV among its four dimensions where the AVE was higher than the SV for all four dimensions, a result that was in agreement or consistent with FornellLarcker Criterion.

\section{References}

[1] Armstrong, M. and Murlis, H. 2004. Reward management: a handbook of remuneration strategy and practice. 5th edition. London: Kogan Page Limited.

[2] Browne, M. W., \& Cudeck, R. (1993).Alternative ways of assessing model fit. "Sage. Focus Editions, $154,136$.

[3] Business Dictionary website. 2010. http://www.businessDictionary.com/definition/perfor mance.html (accessed 17 May 2010).

[4] Mathis, R.L. and Jackson, J.H. 2009.Human Resource Management.

[5] Mason, OH, USA: South-Western Cengage Learning.

[6] Meyer, J.P. and Allen, N.J. 2006.Commitment in the Workplace: Theory, Research, and Application, Thousand Oaks, Sage Publications, New York, USA, $3^{\text {rd }}$.ed

[7] McDonald, R. P., \& Marsh, H. W. (1990).Choosing a multivariate model: No centrality and goodness of fit. "Psychological Bulletin", 107 (2), 247-255.

[8] Marsh, H. W., \& Hocevar, D. (1985).Application of confirmatory factor analysis to the study of selfconcept: First-and higher order factor models and their invariance across groups. "Psychological bulletin", 97 (3), 562-582.http://dx.doi.org/10.1037/00332909.97.3.562
[9] Gibson, J.W. 1990. The supervisory challenge principles and challenges. Ohio: Merrill Publishing Company.

[10] Sultan, Th., Nazim, A., Qader, B. and Khan, Z. (2010). Relationship between Organizational Commitment and Organizational operating performance, Journal of Business and Management, 1 (2) : 41-53

[11]Uzma Hafeez. (2015).Impact of Training on Employees Performance" (Evidence from Pharmaceutical Companies in Karachi, Pakistan).Business Management and Strategy. Vol. 6, No. 1.PP.49.64 